\title{
Measures taken by Russian universities to perform the sustainable development goals in the framework of the third mission
}

\author{
Tatyana Chernysheva* \\ Novosibirsk State Technical University
}

\begin{abstract}
The paper describes the measures taken by Russian universities to implement the Sustainable Development Goals proclaimed by the United Nations in 2015. These goals are in line with the Third Mission activities of a modern university. The core argument is that an environmentally sound interaction should be formed in the depths of educational ecosystems, resulting in an ecological culture. It is advisable to start the transition to a new type of development at universities, since only in this case Russian technologies will eventually meet the environmental requirements. The paper considers the initiatives of the leading Russian universities to introduce economic and social changes aimed at satisfying the needs not only of the living, but also of the future generations [1].
\end{abstract}

\section{Integrating Sustainable Development Goals into university strategies}

Every self-respecting commercial and non-profit organization considers it its duty to adhere to the Sustainable Development Goals. In the economy, the environmental trend is manifested in such a category as "non-financial reporting", which reflects corporate efforts towards social development and environmental initiatives. Nowadays, these issues can undoubtedly have an impact on financial performance. Universities of the world do not remain aloof about the concept of sustainable development $[2,3]$.

Russian universities are also beginning to get closer to the ideas of investing in environmental protection, and the "green" lifestyle of both the living and future generations [4].

Universities should certainly devote as much research, as well as educational programs for undergraduate, graduate and postgraduate students, as possible to the subjects related to sustainable development. Specialized Master's Programs should be formed. There is a need for in-depth scientific research on sustainable development, to which open access should be arranged. Attention should be paid to advancing professional qualifications of university lecturers and the overall staff in this field. Literacy assessment of the faculty and students by both university experts and invited UN representatives should be consonant with the high

\footnotetext{
* Corresponding author: chernysheva@corp.nstu.ru
} 
level of student social innovations and the expanding pool of sustainable development projects.

How can universities adhere to the Sustainable Development Goals? It should be noted that all these goals correspond to the third - social - mission of a university, which has become particularly relevant today due to the search for new management mechanisms enabling transformation into universities 3.0 as well as the social dominant highlighted by the pandemic. There should be a balance between economic, environmental and social development, which is the goal of the Third Mission, making it a university contribution to the national and regional socio-economic development [5].

\section{Advertence of public figures and scientists to the ideas of sustainable development}

Materials from open sources on the websites of Russian universities are analyzed, using such empirical research methods as description and observation. Considerable interest of foreign colleagues in this filed should be emphasized. A number of peer-reviewed journals, for example, "Sustainable Development", "Ecosystem Health and Sustainability", "Nature", "Frontiers in Ecology and the Environment" exist, while the "International Journal of Sustainability in Higher Education" focuses particularly on sustainable development in the university environment. Over the previous year, a lot of research papers were published on various aspects of sustainable development, including the role of higher education institutions $[6,7,8,9,10,11,12]$.

Let's consider what initiatives of Russian universities meet the UN goals related to the "man-nature" ecosystem, i.e. Nos. 3, 6, 7, 12, 13, 14, 15 goals.

\section{The activity of Russian universities towards implementing the Sustainable Development Goals}

Goal 3 "Good Health and Well-Being" involves providing competent class schedules, physical training, robust work of psychological and social services, regular medical examinations and assistance to students and university staff, as well as creating a data bank on their health status and helping them to get rid of any harmful habits. It also includes monitoring sanitary-and-hygienic conditions at a university, rehabilitation, and student adaptation through different stages of their education. Many major universities have established special facilities for preventative purposes (profilaktorii) that offer immuneboosting and performance-enhancing treatment courses. The health status of each member of the university community is examined and, depending on a combination of individual factors, a treatment program - a series of interrelated revitalizing procedures - is prescribed. For example, NSTU offers such services as electro-phototherapy, laser therapy, therapeutic baths and showers, ozocerite (mineral wax) - paraffin therapy, therapeutic massage, hydromassage, and dietary nutrition on the basis of the university profilaktorii [13].

Significant attention to health-saving technologies is paid at St. Petersburg State University, Moscow State University, Kant University, Bauman University, and Novosibirsk State University. Universities have swimming pools, gyms, stadiums, hockey fields, where landmark sport-and-wellness events are organized. For example, MIPT holds the 24-hour "Football Match of the Century" and "Swim of the Century" rooted in its corporate culture. These events are attended by students and the alumni. Ski races, darts, track-and-field athletics, volleyball and chess tournaments have also become traditional for MIPT are [14]. MSU monitors the well-being of laboratory animals in the vivariums of the university clinic and research centers regularly [15]. 
Regarding Goal 6 - "Clean Water and Sanitation”, let's cite university innovations in this area as an example. The environmental monitoring system developed at NSTU is a software and hardware complex called WDAS, which displays current indicators of concentration of small, medium and large particles in the air and transmits the information to the monitoring center. Indicators on wastewater, soil, and atmospheric pollution, found not only in industrial enterprises and landfills, but also in urban built-up areas, are also displayed [13].

TPU has taken the challenge to develop innovations for fresh water reservation and purification, preventing the ingress of pollutants into the waterways of the region. This is done by future hydroengineers, who are trained at the Engineering School of Natural Resources.

Recently established at TPU, the Water Institute is engaged in water treatment, chemical treatment and development of methods for proper use of river, lake and sea water reserves. For example, a recently developed water treatment complex "Geyser TM" is designed for a thorough and multi-component treatment of water from underground sources making it ready to use for drinking and cooking. The "Mongoose" system provides "green" water filtration that prevents settling of harmful salts in heating installations, cold and hot water supply channels, and cleanses and disinfects industrial waste water from all kinds of toxins - bacteria and radioactive elements [16].

MIPT Laboratory of Functional Organic and Hybrid Materials has designed polyelectrolyte-based filters to extract harmful impurities, particularly, all kinds of salts from water. Different wastewater treatments are being successfully developed. The laboratory has developed a device that, when connected to a smartphone, is able to analyze water properties of water in any organization [14]. Another factor taken into account to assess fulfillment of Goal 6 is the sanitation rules observed by universities, such as airing, compliance with the proper indicators of illumination with fluorescent lamps at workplaces, and non-hazardous devices with Internet-access.

Clean energy (Goal 7) generally refers to the ocean energy (waves, high - low tides), biomass, wind, and the sun. Today, the share of solar, wind and small hydropower in Russia is less than $1 \%$ of the total power generation. Universities that have adopted special programs to promote wind and solar energy, biogas, biomass, and landfill gas certainly are at the cutting edge of the industry.

Constructing their buildings and dormitories, modern universities adhere to the "green" process standards. In particular, the new MIPT boiler house emits much less $\mathrm{CO}_{2}$ per $\mathrm{kW} / \mathrm{h}$ into the environment, supplying heat not only to the campus but also to some other urban objects. At energy faculties, students learn about use of secondary energy resources, new renewable energy reserves, and transformation of the ocean power as well as activity of the sun, wind and geothermal sources. [14].

MPEI [17], MEPHI [18], SPBU [19], Peter the Great Polytechnic University [20], Kazan State Energy University [21], Ural Federal University [22], MSU [15] conduct research in the field of alternative energy. For example, the MSU Laboratory of Renewable Energy Sources presents data on energy potentials and the dynamics of the renewal of secondary energy resources - biomass of solid household, agricultural and industrial waste. Pacific State University is working on a "mini-thermal power plant" (TPP) - an installation with a portable internal combustion engine that uses wood debris as the main fuel [15].

NSTU scholars have created a system for predicting solar energy production based on a neural network: using open weather data, an automated system predicts electric power generation with an accuracy of up to $90 \%$ [13].

Responsible Production and Consumption (Goal 12) should start with a university campus becoming a smart experimental laboratory to test air and climate monitoring, inventory emissions, including greenhouse gases, pursue landscape management and biodiversity, and use clean renewable energy. Minimization of waste, its smart disposal, 
reduction of carbon emissions are achieved through encouraged use of bicycle transport, public green spaces and eco-friendly cleaning of university premises and grounds, as well as cost analysis.

University programs are now geared to shape environmental thinking and responsible consumption skills. Waste recycling, use of long-cycle products and renewable resources practices are conveyed and replicated. The emphasis is placed on environmental compatibility of economic activities, energy saving, separate waste collection and responsible consumption. "Green" development is also achieved by universities through research projects, management of university activities on the basis of resource conservation, waste collection and transformation, eco-education and advocacy of ecological culture. Universities form valuable eco-habits by means of useful practices, which support efficient use of resources and energy ("green" administration).

Universities follow the concept of sustainable development through participation in various environmentally-oriented entities. For example, the Association of Green Universities of Russia, with over 80 member-universities, is guided by the goal of introducing a variety of resource-saving practices into their educational process. The Association includes HSE [23], MGIMO University [24], RUDN University [25], and St. Petersburg State University [26]. Arctic Federal University named after M. V. Lomonosov in Arkhangelsk was branded as the greenest university [27, 28].

What are the means to combat climate change (Goal 13)? Today, the amount of greenhouse gas emissions in industrial cities is too high, so faculty and students are replacing cars with public transport and bicycles as the main means of transportation. Walking is promoted as an indispensable attribute of a healthy lifestyle.

Members of university communities are made aware of the projected reduction of meat consumption in favor of vegetables and fruits since production and transportation of meat products is fraught with the release of large amounts of carbon dioxide. It is advisable to use regional, seasonal produce, buying as much as a person plans to consume. Almost any product, except foods, can be reused; furthermore, it is necessary to strive to curtail the scale of consumption in general.

HSE Climate Change Research and Training Laboratory is the first sector-specific laboratory in Russia [23]. Seven federal universities of Russia have joined forces to develop the Russian Arctic. "The Future of the Arctic Architecture and Climate Dynamics" researchand-educational consortium is formed [29]. Russian State Hydrometeorological University has the Center for Arctic and Climate Research [30]. MIPT and MSU scientists make estimates on the impact of anthropogenic atmospheric pollution with methane and carbon dioxide from the Russian territory on the global climate changes in the XXI century [14, 15].

In the course of two large - scale Arctic expeditions organized by MIPT, volcanically active zones of the earth's crust in the Arctic shelf of the East Siberian Sea and the Laptev Sea were investigated and areas of particularly powerful methane emissions were found. Methane emissions contribute significantly to Arctic climate change [14].

Responding to the Goal of "Preserving aquatic ecosystems", universities put forward initiatives to clear up illegal industrial garbage dumps on the coasts of lake- and riversides and seashores, for example, such actions are carried out regularly by volunteer groups from St. Petersburg State University [19]. Universities are developing innovative facilities for water resources treatment and storage.

The current advancements include monitoring interactions within "man-lake", "man river", "man-ocean" systems are monitored; supporting the work of nature reserves and protected natural areas to preserve the diversity of aquatic organisms; monitoring water management; and introducing new technologies for all types of human activity in water channels and coastal zones. 
In the 1970s, the Oceanology Department of the Faculty of Geography, St. Petersburg State University launched research on mathematical modeling of aquatic ecosystems, and similar subjects are being studied at Moscow State University and the Higher School of Economics [15, 23]. Universities monitor their water balance and adopt responsible water consumption systems.

Universities advocate sustainable forest management and conservation of forest biodiversity (Goal 15 "Conservation of Terrestrial Ecosystems"). After all, forests give vital resources to the humans - from air to drinking water and food. Forest degradation leads to all plant species losing their natural habitats; it deteriorates freshwater quality, increases soil erosion, causes land degradation and elevated carbon emissions into the atmosphere.

It is possible to stop deforestation and restore degraded forests by expanding the scale of tree-planting. Efforts are underway to preserve and prevent the extinction of endangered species. Almost all universities that offer "Forestry" programs, for example, Tomsk State University [16], Pacific State University [31], Novgorod State University named after Ya. Mudry [32], Siberian State University of Science and Technology named after Reshetnev [33], Petrozavodsk State University [34], Lomonosov NARFU [28], and Volga State Technical University [35] have research projects in this field.

A team of scientists from the Institute of Space Research of the Russian Academy of Sciences, MIPT and the Institute of Water and Environmental Problems of the Siberian Branch of the Russian Academy of Sciences has devised a method for exposing the depth and degree of glaciations of the Earth based on satellite data. A scale to compare the radicals concentration in plants with the air composition in a particular area is proposed, enabling to identify zones that are dangerous and hazardous for humans [14].

\section{The need for a new educational system}

It may be concluded that the leading Russian universities have joined the sustainable development agenda, which largely comports with the targets of the third mission and the related society-centered activities. Involvement in regional issues naturally prompts universities to generate technological responses to the local challenges. It is obvious that the ability of Russia to preserve and increase its natural and human capital in the global green agenda highly depends on Russian universities. They can help solve the problem of accelerated climate changes and prepare the economy for regeneration on new "green" principles. To a large extent, solutions to the simmering problems with food, clean energy, transport corridors, and security depend on innovative university developments. In this regard, it seems necessary to monitor the activities of Russian universities towards implementing the Sustainable Development Goals, which should begin with the construction of a new educational system based on the principles of social responsibility, equality and solidarity with a clearly defined, dominant environmental idea.

\section{References}

1. Report of the World Commission on Environment and Development: Our Common Future (1987), https://sustainabledevelopment.un.org/

2. O. Saadatian, B. Bakhtiar, Sustainable university (2011)

3. J. Martin, J.E. Samels, The sustainable university: Green goals and new challenges for higher education leaders (2012)

4. O.V. Saginova, Yu.L. Saginov, A.I. Grishin, Bulletin of the Kazan Technological University, 15 (21), 214 (2012) 
5. T.L. Chernysheva, The Third Mission of the University: Technologies for the Formation of Thinking in Modern Students (2020)

6. J. Knox-Hayes, Sh. Chandra, J. Chun, Sustainable Development, 29 (2), 363 (2020)

7. S. Sarwar, D. Streimiriene, R. Waheed, Z. Mighri, Sustainable Development, 29 (2), 419 (2020)

8. T. Kong, T. Feng, Yu. Huang, J. Cai, Sustainable Development, 28 (5), 1106 (2020)

9. B. Zhu, C. and B. Dewancker, International Journal of Sustainability in Higher Education, 21 (4), 799 (2020)

10. P. Fuchs, C. Raulino, D. Conceicao, International Journal Of Sustainability in Higher Education, 21 (7), 1477 (2020)

11. E. Almers, The Journal of Environmental Education, 44 (2), 116 (2013)

12. P. Nambiar, K.Sarabhai, Journal of Education for Sustainable Development, 9(1), 1 (2015).

13. NSTU, Novosibirsk State Technical University, https://www.nstu.ru/

14. MIPT, Moscow Institute of Physics and Technology, https://mipt.ru/

15. Lomonosov Moscow State University, https://www.msu.ru/

16. National Research Tomsk State University, http://www.tsu.ru/

17. National research university «MPEI», https://mpei.ru/

18. National Research Nuclear University MEPhI, https://mephi.ru/

19. SPBU, Saint Petersburg University, https://spbu.ru/

20. Peter the Great St.Petersburg Polytechnic University, https://www.spbstu.ru/

21. KSPEU, Kazan State Power Engineering University, https://en.kgeu.ru/

22. Ural Federal University, https://urfu.ru/ru/

23. HSE University, https://www.hse.ru/

24. MGIMO University, https://mgimo.ru/

25. Peoples' Friendship University of Russia, https://www.rudn.ru/

26. SPBU, Saint Petersburg University, https://spbu.ru/

27. Association of Green Universities of Russia, http://зеленыевузы.pф/

28. Northern (Arctic) Federal University named after M.V. Lomonosov, https://narfu.ru/

29. Research and Educational Consortium | The Future of the Arctic Architecture and Climate Dynamics, https://futurearctic.ru/

30. Russian State Hydrometeorological University, http://www.rshu.ru/

31. Pacific States University, http://www.psuca.edu/

32. Yaroslav-the-Wise Novgorod State University, https://www.novsu.ru/

33. Siberian State Aerospace University, http://en.sibsau.ru/

34. Petrozavodsk State University, https://petrsu.ru/

35. Volga State University of Technology, https://eng.volgatech.net/ 